\title{
Monitoring status, habitat features and amphibian species richness of Crested newt (Triturus cristatus superspecies) ponds at the edge of the species range (Salzburg, Austria)
}

\author{
A. Maletzky*, M. Kyek², A. Goldschmid ${ }^{1}$ \\ ${ }^{1}$ University of Salzburg, Department of Organismic Biology, Hellbrunnerstrasse 34, A-5020 Salzburg. \\ ${ }^{2}$ Institute of Ecology, Johann Herbst Strasse 23, A-5061 Elsbethen.
}

\begin{abstract}
We studied the status of Crested newt (Triturus cristatus superspecies) ponds in the province of Salzburg during the years 2004 and 2005. Historical and current distribution data were collected and compared. In the end of 2004, 51 ponds with Crested newt records of which 39 still existed were known in Salzburg. In 2005 we carried out a monitoring of these ponds using a combination of three survey methods. Presence or absence of adult and larval Crested newts and the number of syntopic amphibian species were recorded. Detection probabilities and the effects of seven characteristic pond features on pond occupancy were calculated for adult and larval newts separately. We observed a strong decline of ponds occupied by Crested newts with presence of adults in 22 and presence of larvae in 16 surveyed ponds, respectively. Detection probabilities imply that we detected all ponds occupied by adults and larvae. Key habitat features for Crested newt presence are low degree of shading for adults and larvae as well as a high density of submerged vegetation for larvae. Pond size and depth are not significant. Furthermore we recorded a significantly higher number of amphibian species in ponds occupied by Crested newts. Our results might aid in the implementation of sustainable measures for a conservation of these critically endangered species in the province of Salzburg.
\end{abstract}

Keywords: Habitat features, monitoring, pond occupancy, Salzburg, Triturus cristatus superspecies.

\section{Introduction}

During the past decades a decline of amphibian populations in many parts of the world has been observed (e.g. Wake 1991, Houlahan et al. 2000). There are several hypotheses to account for this decline on the global scale. Most probably a combination of many factors is responsible (Collins \& Storfer 2003). In the case of the highly urbanised and developed countries of Central and Western Europe, the major factor is without doubt the loss of natural and functioning pond networks (Oertli et al. 2005), due to destruction and manipulation of wetlands and ponds (e.g. Corbett 1989, Beebee 1997, Wood et al. 2003).

The province of Salzburg (Austria) consists of a variety of habitats within a vertical range of 380 to $3600 \mathrm{~m}$ above sea level. Hence there exists a great variety of pond types facing many different threats. Especially in the lowland areas of the North and the inner alpine river valleys, the number of ponds in natural conditions has decreased throughout the past decades due to intensive anthropogenic pressure and land use. Most of the remaining ponds are artificial and often densely

\footnotetext{
* Corresponding author : E-mail : andreas.maletzky@sbg.ac.at
}

stocked with fish and waterfowl (Kyek \& Maletzky 2006). At present the occurrence of 15 amphibian species is documented, of which 13 are reproducing in standing water bodies. Four species have been classified as critically endangered in the current regional Red List of amphibians and reptiles, including the two occurring Crested newt species (Triturus cristatus, Laurenti 1768 and Triturus carnifex, Laurenti 1768) (Kyek \& Maletzky 2006).

Crested newts (Triturus cristatus superspecies) are distributed over great parts of Europe with populations showing significant declines in large parts of this area (Gasc et al. 1997). As these species are listed in Annex II and IV of the EU-habitats directive 92/43/EEC as well as Annex II of the Bern Convention, their conservation status is of European importance. The populations in the province of Salzburg are of special interest, being located in a part of their distribution areas, where the two species can be found narrowly sympatric and hybrid populations exist (e.g. Freytag, 1978, Thiesmeier \& Kupfer 2000, Arntzen 2003). For this study we therefore stick to the taxon Triturus cristatus superspecies. The results of a survey on the identification of the species using molecular methods are in preparation (Maletzky unpublished data). 
Due to their wide distribution area Crested newts inhabit a variety of pond types. Generally these water bodies can be described as large and deep with submerged vegetation and absence of fish (Arntzen 2003). The characteristics of suitable ponds depend more on the particular landscape features than on the particular species (e.g. Cabela \& Grillitsch 2001, Arntzen 2003). The quality and quantity of these characteristics in part determines the presence and size of the populations (Oldham et al. 2000).

Monitoring the distribution and the key habitat features is among the most important requirements for the effective conservation management of threatened species at regional level. A major problem with most monitoring programs is that species are detected imperfectly, which might lead to biased estimates of population trends (MacKenzie et al. 2002, Schmidt 2005). A determination of key habitat features can serve as a basis for detecting the likelihood of occurrence and a guideline for habitat enhancement and creation.

Already several studies dealt with the selection and suitability of amphibian breeding habitats using multivariate analysis (Pavignano et al. 1990), discriminant analysis (Swan \& Oldham 1994) or logistic regression (Laurila 1998). Key habitat criteria for Crested newt species have been evaluated mainly in core distribution areas of T. carnifex (Pavignano et al. 1990) and of T. cristatus (Oldham et al. 2000).

The aims of this study are (1) to evaluate the status of Crested newts in the province of Salzburg, (2) to identify key habitat features for their occurrence in ponds, and (3) to develop standards for the creation or enhancement of ponds supporting these critically endangered species at the edge of their distribution range.

\section{Materials and methods}

\section{Study area}

The study area covers the three northern districts of the province of Salzburg ("Salzburg Stadt", "Salzburg Land", "Hallein"), with a total area of $1777 \mathrm{~km}^{2}$. The main landscape features are the valley of the lower Salzach River, parts of the northern Limestone Alps, Flysch zone and the foothills of the Alps with the lake district (Fig. 1).

\section{Historical data}

Although there are some historical records on the occurrence of Crested newts in Salzburg (e.g. Wolterstorff 1925, Schüller 1963, Freytag 1978), data on precise localities and structure of ponds are scarce. Some information could be drawn from unpublished

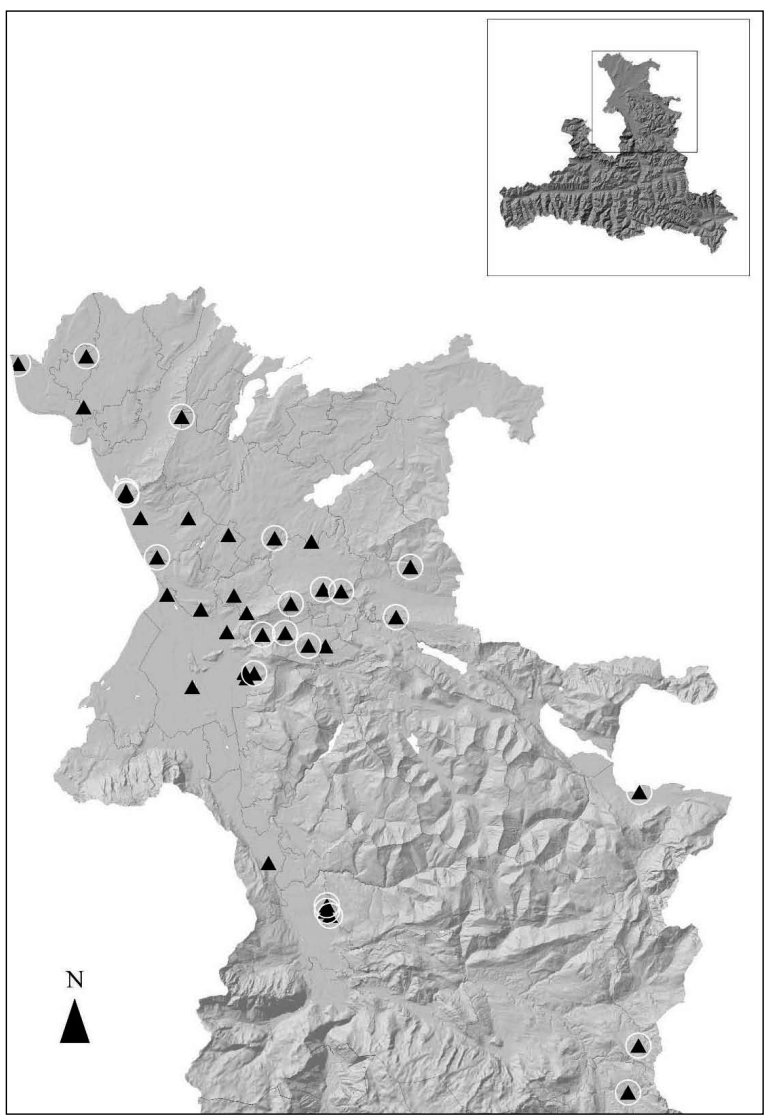

Fig. 1 Geographical distribution of monitored Crested newt (Triturus cristatus superspecies) ponds in 2005. Solid triangle $=$ unconfirmed localities $(\mathrm{n}=16)$; Encircled solid triangles $=$ confirmed localities $(n=22)$.

mapping projects (Kyek unpublished data) and the collection of L. Schüller located in the Natural History Museum "Haus der Natur", Salzburg. Geographical coordinates $( \pm 100-500 \mathrm{~m})$ and habitat descriptions of the origin of preserved specimens were attributed to each record as precise as possible. Together with more recent records collected by the authors, Crested newts were known from 44 ponds between the years 1949 and 2003.

\section{Monitoring}

We examined the status of the 44 ponds with previous records of Crested newts in 2004 and carried out a monitoring of the ponds that were still existing as well as new found localities in 2005. Presence or absence of Crested newt adults and larvae as well as syntopic amphibian species was recorded during three visits per pond between April and July. We used a combination of detection methods with bottle traps, night 
counting and dip-netting. Bottle traps were the main tool for detection and used in each of the three surveys. Such traps are especially useful for presence-absence surveys in ponds that are big or otherwise difficult to examine (Griffiths 1985). We used a minimum number of 10 traps per pond and placed one trap at least every 5 meters. Traps were positioned mainly in shallow water areas with an angle of about $45^{\circ}$. A small perforated part remaining above the water surface allowed the captured individuals to breathe $(\mathrm{H}$. Schedl, pers. comm.). The traps were active overnight from late afternoon to the following morning. The second visit was accompanied by additional night counting, while the third visit was especially focussed on the detection of larvae by means of dip-netting.

\section{Habitat features}

We recorded the particular pond type using the standardized mapping form for monitoring the Austrian herpetofauna (Kyek 1996). Furthermore we recorded 7 habitat features for Crested newt ponds including pond area $\left(\mathrm{m}^{2}\right)$, maximum depth in three classes $(<30 \mathrm{~cm}, 30-100 \mathrm{~cm},>100 \mathrm{~cm})$, fish presence or absence, origin (natural or artificial), and presence or absence of human use. We also estimated density of submerged vegetation (in $25 \%$-classes) and proportion of shade (in $25 \%$-classes).

\section{Data analysis}

All mapping and monitoring data were processed with BioOffice-databanking (CBiogis) and ArcView 9.1 for GIS (C) Esri). For the monitoring data of the year 2005 we estimated detection probabilities and the proportion of sites occupied by adults and larvae separately, using the mark recapture like approach of MacKenzie et al. (2002, 2005). The analysis was done with the software Presence 2.0. The effects of habitat variables on the presence of Crested newts, adults and larvae, were analysed by means of logistic regression, which was performed with $\mathrm{R}$ freeware (R Development Core Team 2005). We used the Firth's bias $r$ educed logistic regression implemented in the LOGISTF-package (Ploner et al. 2006).

\section{Results}

\section{Status and monitoring of Crested newt ponds}

While $32(72.7 \%)$ ponds with old records still exist, all ponds with records before 1977 have been destroyed. In contrast, we recorded Crested newt presence in 7 ponds which were evaluated for the first time in the two study years. Therefore to date, 39 (out of a total of 51 records) Crested newt ponds are known in the province of Salzburg. One private garden pond could not be surveyed in the course of this study. During the monitoring of 38 ponds in 2005 the presence of adult Crested newts was recorded for 22 ponds $(57.9 \%)$, larvae were detected in 16 ponds $(42.1 \%)$ (Fig. 1, Tab. 1), while 16 ponds were classified as unoccupied Crested newt ponds (Tab. 2).

We analysed detection probabilities for adults and larvae separately. Therefore we first tested two predefined models that used constant and survey-specific detection probabilities. For both adults and larvae the lower AIC value indicated that the survey-specific P model was better supported by the data and detection probabilities were time specific. The predicted site occupancy using this model was $0.588(\mathrm{SE}=0.082)$ for adults and $0.431(\mathrm{SE}=0.081)$ for larvae, respectively (Tab. 3). While detection probabilities (P) for adults were high in all three surveys ranging from 0.640 to 0.951 , detection probabilities for larvae were very low in the first two surveys but high (i.e. $\mathrm{P}=1.000$ ) in the third one (Tab. 4). These results imply that we detected all the ponds where adult and larval Crested newts were present.

\section{Habitat features of studied ponds}

The mean water surface area of studied ponds $(\mathrm{n}=38)$ was $342.2 \mathrm{~m}^{2}\left( \pm 425.2 \mathrm{~m}^{2}\right.$ std. dev.) with a range of 20-2000 $\mathrm{m}^{2}$. The majority of ponds showed maximum depths of $30-100 \mathrm{~cm}(56.4 \%)$, while a maximum depth of more than 1 meter was recorded for 16 ponds $(41.0 \%)$. Only one pond had a maximum depth of less than $30 \mathrm{~cm}$. Fish presence was recorded for $8(21.1 \%)$ ponds, three of them being densely stocked.

Artificial ponds (71.1\%) were built for purposes like fish breeding, ice stock sliding in winter and fire protection. One brewery ice pond that was created to have a cheap possibility of cooling is now used extensively for fish breeding. Private garden ponds are used for swimming or ornamental reasons. Eight ponds $(20.5 \%)$ were created in the course of nature conservation projects since 1991. The habitat feature human use contains $25(65.8 \%)$ of these ponds that are periodically managed and succession is interrupted, which is beneficial for amphibian populations. Thirteen ponds $(34.2 \%)$ are not used currently and thus subject to strong succession.

The proportion of average area covered by submerged vegetation was $0-25 \%$ in 17 ponds, $26-50 \%$ in 11 and $51-75 \%$ in 9 ponds respectively. Only one pond had 75-100\% submerged vegetation cover. 
Table 1. Characteristics of occupied Crested newt ponds in $2005(n=22)$. Pond types: $a=$ natural; $b=$ heavily modified; $c=$ garden pond; $d=$ peat bog cut; $\mathrm{e}=$ ditch (stagnant)

\begin{tabular}{|c|c|c|c|c|c|c|c|c|c|c|c|}
\hline $\begin{array}{l}\text { Locality } \\
\text { Name }\end{array}$ & $\begin{array}{l}1^{\text {st }} \\
\text { record } \\
\text { (year) }\end{array}$ & $\begin{array}{l}\text { Area } \\
\left(\mathbf{m}^{2}\right)\end{array}$ & $\begin{array}{l}\text { Maximum } \\
\text { depth } \\
\text { (cm) }\end{array}$ & $\begin{array}{l}\text { Larvae } \\
\text { presence }\end{array}$ & $\begin{array}{l}\text { Fish } \\
\text { presence }\end{array}$ & $\begin{array}{l}\text { Pond } \\
\text { Type }\end{array}$ & $\begin{array}{l}\text { Arti- } \\
\text { ficial }\end{array}$ & $\begin{array}{l}\text { Submerged } \\
\text { Veg. (\%) }\end{array}$ & $\begin{array}{l}\text { Shade } \\
(\%)\end{array}$ & $\begin{array}{l}\text { Human } \\
\text { use }\end{array}$ & $\begin{array}{l}\text { Syntopic } \\
\text { species }\end{array}$ \\
\hline Irlach & 1981 & 300 & $30-100$ & + & - & $a$ & - & $51-75$ & $51-75$ & - & 6 \\
\hline Zecherl & 1999 & 40 & $>100$ & + & - & $b$ & + & $51-75$ & $0-25$ & + & 2 \\
\hline WeitwörthA1 & 1996 & 100 & $30-100$ & + & - & a & + & $26-50$ & $26-50$ & + & 6 \\
\hline WeitwörthM1 & 1996 & 400 & $>100$ & + & - & $\mathrm{a}$ & + & $26-50$ & $26-50$ & + & 7 \\
\hline WeitwörthM2 & 1996 & 100 & $30-100$ & + & - & a & + & $26-50$ & $51-75$ & + & 6 \\
\hline Guggenthal & 1996 & 500 & $>100$ & + & + & b & + & $51-75$ & $26-50$ & + & 4 \\
\hline Freimoos 1 & 1992 & 300 & $30-100$ & + & - & e & + & $51-75$ & $0-25$ & + & 5 \\
\hline Freimoos 2 & 2005 & 400 & $>100$ & + & - & a & + & $76-100$ & $0-25$ & + & 5 \\
\hline Freimoos3 & 2003 & 200 & $>100$ & + & - & $\mathrm{a}$ & + & $0-25$ & $0-25$ & + & 6 \\
\hline Achleiten & 1984 & 300 & $>100$ & - & + & a & + & $0-25$ & $0-25$ & + & 6 \\
\hline Ameisensee & 1998 & 1500 & $>100$ & + & - & $\mathrm{a}$ & - & $0-25$ & $51-75$ & - & 5 \\
\hline Annaberg & 1992 & 100 & $30-100$ & - & - & c & + & $0-25$ & $0-25$ & + & 3 \\
\hline Bürmoos & 2001 & 30 & $30-100$ & + & - & c & + & $51-75$ & $26-50$ & + & 3 \\
\hline Unterkoppl & 2003 & 300 & $30-100$ & + & + & $\mathrm{a}$ & + & $51-75$ & $51-75$ & + & 6 \\
\hline Seekirchen & 1981 & 500 & $30-100$ & + & - & a & + & $51-75$ & $51-75$ & + & 4 \\
\hline Neuhofen & 2004 & 120 & $30-100$ & + & - & a & + & $26-50$ & $0-25$ & + & 4 \\
\hline Sommeregg & 1981 & 250 & $>100$ & + & - & $\mathrm{a}$ & - & $26-50$ & $0-25$ & - & 2 \\
\hline Strobl & 2005 & 200 & $30-100$ & + & - & a & + & $26-50$ & $26-50$ & - & 3 \\
\hline Koppl & 2005 & 300 & $30-100$ & - & - & d & + & $0-25$ & $26-50$ & + & 3 \\
\hline Reitberg & 2005 & 700 & $>100$ & - & - & a & + & $0-25$ & $0-25$ & + & 4 \\
\hline Siggerwiesen & 2005 & 20 & $30-100$ & - & - & a & - & $0-25$ & $51-75$ & - & 3 \\
\hline Gaisberg & 2005 & 100 & $>100$ & - & - & c & + & $0-25$ & $51-75$ & + & 5 \\
\hline
\end{tabular}

Table 2. Characteristics of unoccupied Crested newt ponds in $2005(n=16)$. Pond types: $a=$ natural; $b=$ heavily modified; $c=$ garden pond; $f=$ puddle

\begin{tabular}{|c|c|c|c|c|c|c|c|c|c|c|c|}
\hline Locality Name & $\begin{array}{l}1^{\text {st }} \\
\text { record } \\
\text { (year) }\end{array}$ & $\begin{array}{l}\text { Last } \\
\text { record } \\
\text { (year) }\end{array}$ & $\begin{array}{l}\text { Area } \\
\left(\mathrm{m}^{2}\right)\end{array}$ & $\begin{array}{l}\text { Maximum } \\
\text { depth } \\
\text { (cm) }\end{array}$ & $\begin{array}{l}\text { Fish } \\
\text { presence }\end{array}$ & $\begin{array}{l}\text { Pond } \\
\text { type }\end{array}$ & $\begin{array}{l}\text { Arti- } \\
\text { ficial }\end{array}$ & $\begin{array}{l}\text { Submerged } \\
\text { Veg. (\%) }\end{array}$ & $\begin{array}{l}\text { Shade } \\
(\%)\end{array}$ & $\begin{array}{l}\text { Human } \\
\text { use }\end{array}$ & $\begin{array}{l}\text { Syntopic } \\
\text { species }\end{array}$ \\
\hline Sam & 1993 & 1993 & 40 & $30-100$ & - & c & + & $51-75$ & $51-75$ & + & 2 \\
\hline Leopoldskron & 1992 & 1992 & 40 & $<30$ & - & $\mathrm{f}$ & - & $0-25$ & $76-100$ & - & 1 \\
\hline Loipferding & 1992 & 1992 & 100 & $30-100$ & - & $\mathrm{a}$ & - & $0-25$ & $76-100$ & - & 4 \\
\hline Hallein & 1992 & 1992 & 100 & $30-100$ & - & a & + & $26-50$ & $51-75$ & - & 3 \\
\hline Gaglham & 1993 & 1999 & 400 & $30-100$ & - & a & - & $0-25$ & $76-100$ & - & 3 \\
\hline Fürwag & 2003 & 2003 & 40 & $30-100$ & - & a & - & $51-75$ & $76-100$ & - & 2 \\
\hline Willischwandt & 2003 & 2003 & 2000 & $>100$ & + & b & + & $0-25$ & $0-25$ & + & 2 \\
\hline Mayrwies & 1997 & 1997 & 20 & $30-100$ & - & c & + & $26-50$ & $51-75$ & + & 1 \\
\hline Berndorf & 1983 & 1983 & 75 & $30-100$ & - & b & + & $0-25$ & $51-75$ & + & 2 \\
\hline Unterhaging & 1980 & 1984 & 500 & $>100$ & + & b & + & $0-25$ & $26-50$ & + & 2 \\
\hline Acharting & 1981 & 1994 & 600 & $>100$ & + & a & - & $25-50$ & $51-75$ & + & 4 \\
\hline Würmassing & 1977 & 1981 & 300 & $30-100$ & - & $\mathrm{a}$ & + & $0-25$ & $26-50$ & + & 1 \\
\hline Koppl Winkl & 1976 & 1977 & 400 & $>100$ & + & $\mathrm{a}$ & - & $0-25$ & $76-100$ & - & 2 \\
\hline Mayerlehen & 1982 & 1982 & 300 & $30-100$ & - & $\mathrm{a}$ & - & $0-25$ & $76-100$ & - & 1 \\
\hline Moosham & 1977 & 1977 & 250 & $30-100$ & - & a & + & $26-50$ & $51-75$ & + & 2 \\
\hline Hallwang Berg & 1995 & 1995 & 500 & $>100$ & + & a & + & $26-50$ & $51-75$ & - & 2 \\
\hline
\end{tabular}

The average degree of shade was $0-25 \%$ for 10 ponds, $26-50 \%$ for 8 ponds. 14 ponds showed a proportion of $51-75 \%$, while only 6 ponds showed a proportion of 76-100\% (Tabs 1 and 2).

Ponds occupied by Crested newts in 2005 showed a total number of 3-7 co-occurring amphibian species
$($ mean $=4.45$, mode $=6)($ Fig. 2; Tab. 1), while 1-4 amphibian species $($ mean $=2.13$, mode $=2)$ were detected in unoccupied ponds (Fig. 2, Tab. 2).

Table 5 displays the results of logistic regression analysis for effects of seven habitat features on pond occupancy by Crested newt adults and larvae. 
Table 3. Probability of site occupancy for Triturus cristatus superspecies in 2005. Naïve proportion is the observed proportion of occupied sites, $\psi$ is the estimated proportion of occupied sites and SE $(\psi)$ is the standard error of $\psi$. Models with lower AIC are better supported by the data.

\begin{tabular}{llllllll}
\hline & Model & N & -2log-likelihood & AIC & Naive proportion & $\Psi$ & SE $(\Psi)$ \\
$\ldots$ Adults & Survey specific P & 38 & 98.342 & 106.342 & 0.579 & 0.588 & 0.082 \\
& Constant P & 38 & 105.968 & 109.968 & 0.579 & 0.592 & 0.082 \\
\multirow{2}{*}{ Larvae } & Survey specific P & 38 & 66.224 & 74.224 & 0.421 & 0.431 & 0.081 \\
& Constant P & 38 & 94.673 & 98.673 & 0.421 & 1.000 & 0.000 \\
\hline
\end{tabular}

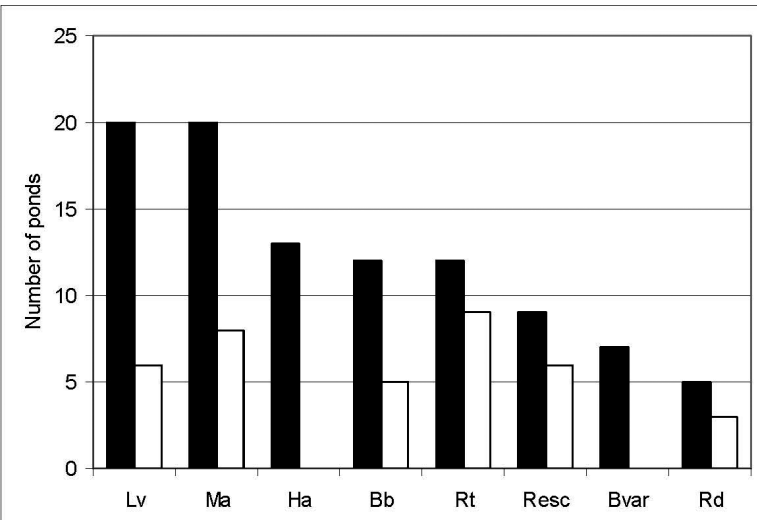

Fig. 2. Frequency of syntopic amphibian species in monitored Crested newt (Triturus cristatus superspecies) ponds in 2005. Solid bars = occupied $(\mathrm{n}=22)$; Empty bars = unoccupied $(\mathrm{n}=16)$; $\mathrm{Lv}=$ Lissotriton vulgaris, $\mathrm{Ma}=$ Mesotriton alpestris, $\mathrm{Ha}=$ Hyla arborea, $\mathrm{Bb}=$ Bufo bufo, $\mathrm{Rt}=$ Rana temporaria, $\mathrm{Resc}=$ Rana esculenta-Komplex, Bvar = Bombina variegata, $\mathrm{Rd}=$ Rana dalmatina.

We found that a low degree of shade is the most important habitat variable with significant results in both adult $(\mathrm{P}>0.001)$ and larval $(\mathrm{P}>0.05)$ presence. The latter was also significantly correlated to a high density of submerged vegetation $(\mathrm{P}>0.001)$, which showed a comparably high but not significant probability in adults. The same is true for the variables human use and pond origin. Pond area, maximum depth and fish presence had no significant effects in both cases.

\section{Species richness}

Regression analyses show a highly significant correlation between presence of Crested newt adults and larvae and the number of co-occurring species $(\mathrm{P}>0,001$; Tab. 5).

Altogether 8 further amphibian taxa could be detected in the surveyed ponds. Of these, Alpine newt
Table 4. Detection probabilities (P) for Triturus cristatus superspecies in 2005 using the survey-specific P model. SE (P) is the standard error for $\mathrm{P}$.

\begin{tabular}{llllll}
\hline & $\mathbf{P}$ (adults) & $\overline{\mathbf{S E}(\mathbf{P})}$ & $\mathbf{P}$ (larvae) & $\mathbf{S E}(\mathbf{P})$ & missing observations (\%) \\
${ } }$ & 0.640 & 0.108 & 0.000 & 0.000 & 18.42 \\
survey 2 & 0.951 & 0.048 & 0.183 & 0.096 & 13.16 \\
survey 3 & 0.891 & 0.072 & 1.000 & 0.000 & 5.26 \\
\hline
\end{tabular}

(Mesotriton alpestris Laurenti, 1768) and Smooth newt (Lissotriton vulgaris L., 1758) were most frequently found in occupied Crested newt ponds $(90.9 \%$ each), while they were present in $50 \%$ and $37.5 \%$ of the unoccupied ponds, respectively. The Tree frog (Hyla arborea L., 1758) was detected in $59.1 \%$ of occupied ponds, while there are no records for unoccupied ones. Likewise the Yellow bellied toad (Bombina variegata L., 1758) was only found in occupied ponds with a frequency of $31.8 \%$. The frequencies of the critically endangered Agile frog (Rana dalmatina Bonaparte, 1840) were comparably low in occupied $(22.7 \%)$ and unoccupied (18.8\%) ponds (Fig. 2).

\section{Discussion}

\section{Status and monitoring of Crested newt ponds}

The occurrence and frequency of Crested newts (Triturus cristatus superspecies) has declined seriously during the last century. One of the main factors for this pattern is the loss or manipulation of suitable breeding habitats (Arntzen 2003). Our study represents the first approach of a species specific monitoring of amphibian breeding ponds in the province of Salzburg. It shows that about $25 \%$ of all recorded ponds with crested newt presence have disappeared and reproduction was observed in less than $50 \%$ of the existing ponds. Comparable data in other regions of central 
Table 5: Results of logistic regression analysis for effects of pond characteristics on occupancy of a) adults and b) larvae: C.I. = Confidence Interval limit; $* *=$ highly significant effect; * significant effect.

\begin{tabular}{|c|c|c|c|c|c|c|}
\hline $\begin{array}{l}\text { a) } \\
\text { Predictor } \\
\text { variable }\end{array}$ & coefficient & $\begin{array}{l}\text { SE } \\
\text { (coefficient) }\end{array}$ & $\begin{array}{l}\text { Lower 95\% } \\
\text { C.I. }\end{array}$ & $\begin{array}{l}\text { Upper } 95 \% \\
\text { C.I. }\end{array}$ & $\mathbf{X}^{2}$ & $\mathbf{P}$ \\
\hline Pond area & -0.0002 & 0.0008 & -0.0018 & 0.0013 & 0.0789 & 0.779 \\
\hline Maximum depth & 0.5238 & 0.6131 & -0.6205 & 1.7414 & 0.8007 & 0.371 \\
\hline Fish presence & -0.8967 & 0.8133 & -2.5102 & 0.5985 & 1.3806 & 0.240 \\
\hline Artificial & 1.0772 & 0.7365 & -0.2882 & 2.5417 & 2.3825 & 0.123 \\
\hline Human use & 1.0462 & 0.7008 & -0.2637 & 2.4326 & 2.4429 & 0.118 \\
\hline Submerged veg. & 0.6263 & 0.4116 & -0.1185 & 1.4804 & 2.6821 & 0.101 \\
\hline Shade & -1.3908 & 0.4686 & 2.4780 & -0.5955 & 13.8652 & $<0.001 * *$ \\
\hline Syntopic species & 1.2989 & 0.4176 & 0.6147 & 2.3547 & 20.4918 & $<0.001 * *$ \\
\hline \multicolumn{7}{|l|}{ b) } \\
\hline Pond area & 0.0001 & 0.0008 & -0.0015 & 0.0016 & 0.0191 & 0.890 \\
\hline Maximum depth & 0.2905 & 0.6094 & -0.8617 & 1.4859 & 0.2446 & 0.621 \\
\hline Fish presence & -0.7675 & 0.8679 & -2.5789 & 0.7698 & 0.9222 & 0.337 \\
\hline Artificial & 0.7492 & 0.7639 & -0.6429 & 2.3082 & 1.0853 & 0.298 \\
\hline Human use & 0.5988 & 0.7123 & -0.7239 & 2.0252 & 0.7730 & 0.379 \\
\hline Submerged veg. & 1.5447 & 0.5147 & 0.6523 & 2.6846 & 13.0971 & $<0.001 * *$ \\
\hline Shade & -0.8128 & 0.3608 & -1.5671 & -0.1643 & 6.1735 & $0.013 *$ \\
\hline Syntopic species & 0.8025 & 0.2697 & 0.3374 & 1.4058 & 13.0787 & $<0.001 * *$ \\
\hline
\end{tabular}

Europe have been published throughout the previous decades. In the German federal state of RhinelandPalatinate the loss of habitats was regarded as $20 \%$ (Bitz \& Simon 1996). In Great Britain regional estimates vary widely from $90 \%$ for parts of London to $6 \%$ for urban ponds in Edinburgh (Wood et al. 2003).

Monitoring projects of Crested newt populations in neighbouring regions showed comparably low occupation levels. In South-Eastern Bavaria 9 out of 20 surveyed ponds were found unoccupied (Gruber, H.-J. unpublished data). In the province of Lower Austria, Klepsch (1994) found Crested newt presence in only 5 out of 14 sites that were occupied ten years before. These data are similar to the decrease of $1.4-2.0 \%$ in population numbers per annum which was estimated for Great Britain (Clemons 1997). The reasons for the declining number of Crested newt populations and habitats in our area are generally related to the fact that these species are restricted to the lowlands and hills in the northern districts. Their distribution area is nearly identical with the main human settlement area, which is underlying increasing pressure from infrastructure and land use. Data on current and historical vertical distribution show that most populations have been lost in the lowlands (Maletzky unpublished data).

Species detection in monitoring studies tends to be imperfect especially for rare species and small populations. If populations are unequally detectable across groups to be compared, results are biased and do not reflect reality (Kery 2004). Such unequal detectability despite the use of standardised methods can for instance be caused by environmental or climatic variables. Statistical methods for estimating site occupancy are useful tools for analysing the significance of monitoring data (MacKenzie et al. 2002) and have been successfully applied for monitoring amphibian distribution in terrestrial (Bailey et al. 2004) and aquatic (Schmidt 2005) habitats. Crested newts might be missed during surveys especially when submerged vegetation is dense and deep water zones are extended (e.g. Beebee 1990). However, Cooke (1995) showed that survey results at a secure site using night counting procedures were positively related to numbers gained by bottle traps. In our study the detection probabilities for both adults and larvae were high compared to a related study dealing with three anuran species (Schmidt 
2005). We did not test climatic effects on our detection histories but personal experience shows that especially bottle traps are effective independent of weather conditions. We achieved the highest detection probability for adult newts in the second survey, probably caused by the combination of night counting and bottle traps. The increasing probability in detection of larvae is most probably explained by the survey dates. Altogether the use of combined methods can in our case be regarded as adequate and successful.

\section{Habitat features of studied ponds}

Many studies in core distribution areas have dealt with the question what might make a good Crested newt pond (e.g. Swan \& Oldham 1994, Oldham et al. 2000). According to Blab \& Blab (1981) shading, pond area and density of submerged vegetation are the three relevant pond characteristics for the abundance of Crested newts. In a study from Western France shading represented a key feature for the abundance of larval Triturus newts, suggesting that the successional stage of the pond is important (Sztatecsny et al. 2004). Our results reflect these findings to a certain degree. Shading and density of submerged vegetation had significant effects on pond occupancy in our study, while pond area was of no importance for Crested newt presence. Cooke et al. (1994) regarded ponds with less than $10 \%$ shade as ideal for populations in Great Britain. In a study from the German province of Lower Saxony Crested newts are missing from ponds with a degree of shading higher than $40 \%$ (Filoda 1981). Although in the province of Salzburg the number of ponds located in open areas is low due to intensive land use, and most of the surveyed ponds are to some extent associated with forests or shrubberies, the majority of occupied ponds showed a degree of shading below $50 \%$. Positive effects of submerged vegetation density were reported by Oldham (1994) who suggested a total macrophyte cover of 70-80\% as ideal for Crested newt ponds. While in our study this effect was high but not significant for adults, we found a highly significant effect for the presence of larvae. Atkins (1998) reported $500-750 \mathrm{~m}^{2}$ as typical pond size for Triturus cristatus in Great Britain. A minimal pond size of $50 \mathrm{~m}^{2}$ and a minimal pond depth of $50 \mathrm{~cm}$ are given as key figures for the whole superspecies, with T. carnifex being the species with the highest ecological amplitude (Arntzen 2003). In areas with high densities of Crested newt populations, pond size and depth play an important role, because there are simply more ponds to choose from. For Crested newt larvae there is some evidence that intermediate pond sizes may be favourable (Van Buskirk 2005). In Salzburg these features have no significant effects on their presence. Perhaps here the low number of ponds forces them to take what they can find.

The manipulation of ponds by means of fish introduction is one of the major causes for population declines throughout many parts of the distribution range of Crested newts (Thiesmeier \& Kupfer 2000). This habitat variable showed no significantly negative effect in our study. Possible explanations might be that on the one hand introduction of fish into most of our studied ponds happened very recently and the number of fish is very low in some cases.

\section{Species richness}

In the province of Salzburg ponds occupied by Crested newts in most instances represent aquatic habitats of high value for amphibians in general. We observed significant differences in amphibian species richness between occupied and unoccupied ponds. Especially the Smooth newt (Lissotriton vulgaris) and the Tree frog (Hyla arborea), both listed as endangered in the current Red List (Kyek \& Maletzky 2006), obviously need similar habitat features in our region. This fact can also be observed vice versa, as a practical conservation project in the years 2002 and 2003 showed. Two of our surveyed ponds (Freimoos 2 and Freimoos 3 , see Tab. 1) were created especially for the needs of Tree frogs during a translocation project and were colonised by Crested newts one year after the ponds were created (Kyek et al. in press).

\section{Conclusions and implications for future programmes}

Crested newts (Triturus cristatus superspecies) are at the uppermost level of legal protection in Austria, underlying European (EU habitats directive), national (national Red List) and regional (species protection decree, nature conservation law) regulations. As they are listed in Annex II and IV of the EU habitats directive, the establishment of special protected areas (Natura 2000) as well as monitoring programmes and enhancement measures for aquatic and terrestrial habitats are demanded. Nevertheless a comparably strong decline of population numbers could be observed for no other amphibian species during recent decades and no protected areas have been declared for the needs of these species. At the end of 2005 no occupied Crested newt pond is documented within the range of Natura 2000 areas in Salzburg (Kyek \& Maletzky 2006). The effective conservation status of the Crested newt species (Triturus cristatus, T. carnifex) in this area is critical 
and the high degree of legal protection does not appear to be reflected in conservation benefit. Even intact and frequently reproducing populations show unfavourable conservation status in terms of population sizes, quality of the terrestrial habitat and degree of isolation (Maletzky unpublished data). We strongly call for the initiation of measures to avoid a further decline of these species, not least due to their high significance as indicators of amphibian richness and their great value for science, being located in an area where two species are occurring narrowly sympatric and hybrid populations exist (e.g. Freytag, 1978, Arntzen 2003, Maletzky unpublished data). Crested newts in this area largely depend on artificial ponds. The focus of future conservation efforts must lie in the creation of pond networks, including new artificial ponds as well as the enhancement of old ponds and the parallel development of migration corridors. For aiding as many species as possible, a number of connected smaller ponds may be preferable compared with single large ones (Oertli et al. 2002). Furthermore new ponds should be placed in reachable distances to existing populations and as isolated as possible from human infrastructure preventing the introduction of allochthonous fish and rubbish (Williams et al. 1999).

\section{Acknowledgements}

The authors want to express their gratitude to E. Stüber and A. Cabela for support in collecting historical data. Also we want to thank the members of the Herpetological study group of the museum "Haus der Natur", Salzburg for their help in the field. Special thanks go out to R. Kaiser for his help with statistical problems, H. Schedl for the advice in bottle trap construction and positioning and $\mathrm{J}$. Hollinshead as well as three anonymous referees for their comments on the manuscript. Permits were granted by the Federal Government of Salzburg (Nr. 21301-RI-548/9-2003).

\section{References}

Arntzen J.W. 2003. - Triturus cristatus Superspezies - KammmolchArtenkreis. Pages 422-486 in Handbuch der Reptilien und Amphibien Europas. Grossenbacher K. \& Thiesmeier B. (eds). AulaVerlag, Wiesbaden.

Atkins W. 1998. - "Catch 22" for the great crested newt: Observations on the breeding ecology of the great crested newt Triturus cristatus and implications for the conservation of the species. Brit. Herp. Soc. Bull., 63, 17-27.

Bailey L.L., Simons T.R. \& Pollock K.H. 2004. - Estimating site occupancy and species detection probability parameters fro terrestrial salamanders. Ecol. Appl., 14, 692-702.

Beebee T.J.C. 1990. - Crested newt rescues: how many can be caught? Brit. Herp. Soc. Bull., 32, 12-14.

Beebee T.J.C. 1997. - Changes in dewpond numbers and amphibian diversity over 20 years on chalk downland in Sussex, England. Biol. Cons., 81, 215-219.

Bitz A. \& Simon L. 1996. - Die neue Rote Liste der bestandsgefährdeten Lurche (Amphibia). Pages 615-618 in Die Amphibien und Reptilien in Rheinland-Pfalz. Bitz A., Fischer K., Simon L., Thiele T. \& Veith M. (eds). GNOR, Landau.
Blab J. \& Blab L. 1981. - Quantitative Analysen zur Phänologie, Erfaßbarkeit und Populationsdynamik von Molchbeständen des Kottenforstes bei Bonn. Salamandra, 17, 147-172.

Cabela A. \& Grillitsch H. 2001. - Verbreitung und Ökologie der Amphibien und Reptilien. Pages 164-441 in Atlas zur Verbreitung und Ökologie der Amphibien und Reptilien in Österreich. Cabela A., Grillitsch H. \& Tiedemann F. (eds). Umweltbundesamt, Wien.

Clemons J. 1997. - Conserving great crested newts. Brit. Herp. Soc. Bul., 59, 2-5.

Collins J.P. \& Storfer A. 2003. - Global amphibian declines: sorting the hypotheses. Divers. Distrib., 9, 89-98.

Cooke A.S. 1995. - A comparison of survey methods for Crested newts (Triturus cristatus) and night counts at a secure site, 19831993. Herpetol. J., 5, 221-228.

Cooke S.D., Cooke A.S. \& Sparks T.H. 1994. - Effects of scrub cover on great crested newts breeding performance. Pages 71-74 in Conservation and Management of Great Crested Newts. Gent T. $\&$ Bray R. (eds). English Nature, Peterborough.

Corbett K. 1989. - The conservation of European reptiles and amphibians. Helm, London.

Filoda H. 1981. - Amphibien im östlichsten Teil Lüchow-Dannenbergs - eine siedlungsbiologische Bestandsaufnahme. Beiträge zur Naturkunde Niedersachsens, 34, 125-136.

Freytag G.E. 1978. - Über Triturus cristatus bei Salzburg (Amphibia: Caudata: Salamandridae). Salamandra, 14, 45-46.

Gasc J.P., Cabela A., Crnobrnaja-Isailovic J., Dolmen D., Grossenbacher K., Haffner P., Lescure J., Martens H., Martinez Rica J.P., Maurin H., Oliveira M.E., Sofianidou T.S., Veith M. \& Zuiderwijk A. (eds). 1997. - Atlas of amphibians and reptiles in Europe. Societas Europaea Herpetologica, Muséum National d'Histoire Naturelle \& Service du Petrimone Naturel, Paris, 494 p.

Griffiths R.A. 1985. - A simple funnel trap for studying newt populations and an evaluation in smooth and palmate newts, Triturus vulgaris and Triturus helveticus. Brit. J. Herpetol., 1, 5-10.

Houlahan J.E., Findlay C.S., Schmidt B.R., Meyer A.H. \& Kuzmin S.L. 2000. - Quantitative evidence for global amphibian population declines. Nature, 404, 752-755.

Kery M. 2004 - Extinction rate estimates for plant populations in revisitation studies: importance of detectability. Conserv. Biol., $18,570-574$.

Klepsch L. 1994. - Zur Artdifferenzierung der Kammmolche (T.cristatus-Artenkreis) im Waldviertel: Morphometrische und molekulargenetische Untersuchungen. - Diploma Theses, University of Vienna [unpublished].

Kyek M. 1996. - Erhebungsbogen zur Kartierung der Lurche und Kriechtiere Österreichs. Natur und Land, 82, 19-22.

Kyek M., Maletzky A. 2006. - Atlas und Rote Liste der Amphibien und Reptilien Salzburgs. Stand Dezember 2005. NaturschutzBeiträge, 33, 1-240.

Kyek M., Maletzky A. \& Achleitner S. in press. - Large scale translocation and habitat compensation of amphibian and reptile populations in the course of the redevelopment of a waste disposal site. Zeitsch. Feldherpetol, 17.

Laurila, A. 1998. - Breeding habitat selection and larval performance of two anurans in freshwater rock-pools. Ecography, 21, 484-494.

MacKenzie D.I., Nichols J.D., Lachmann G.D., Droege S., Royle J.A. \& Langtimm C.A. 2002. - Estimating site occupancy rates when detection probabilities are less than one. Ecology, 83, 2248-2255.

MacKenzie D.I., Nichols J.D., Sutton N., Kawanishi K. \& Bailey L.L. 2005. - Improving inferences in population studies of rare species that are detected imperfectly. Ecology, 86, 1101-113.

Oertli B., Auderset Joye D., Castella E., Juge R., Cambin, D. \& Lachavanne, J.-B. 2002. - Does size matter? The relationship between pond area and biodiversity. Biol. Cons., 104, 59-70. 
Oertli B., Biggs J., Cereghino R., Grillas P., Joly P. \& Lachavanne J.B. 2005. - Conservation and Monitoring of pond biodiversity : introduction. Aquat. Conserv. Mar. Freshw. Ecosyst., 15, 535-400.

Oldham R.S. 1994. - Habitat assessment and population ecology. Pages 45-68 in Conservation and Management of Great Crested Newts. Gent T. \& Bray R. (eds). English Nature, Peterborough.

Oldham R.S., Keeble J., Swan M.J.S. \& Jeffcote M. 2000 . Evaluating the suitability of habitat fort he great crested newt (Triturus cristatus). Herpetological Journal, 10, 143-155.

Pavignano I., Giacoma C. \& Castellano S. 1990. - A multivariate analysis of amphibian habitat determinants in north-western Italy. Amphibia-Reptilia , 11, 311-324.

Ploner M., Dunkler D., Southworth H. \& Heinze G. 2006. - logistf: Firth's bias reduced logistic regression. R package version 1.06.

R Development Core Team 2005. - R: A language and environment for statistical computing. R Foundation for Statistical Computing, Vienna, Austria. ISBN 3-900051-07-0, URL http://www. R-project.org.

Schmidt B.R. 2005. - Monitoring the distribution of pond-breeding amphibians when species are detected imperfectly. Aquat. Conserv.: Mar. Freshwat. Ecosyst. Ecosystem., 15, 681-692.

Schüller L. 1963. - Die Amphibien und Reptilien des Landes Salzburg. Pages 101-108 in Die naturwissenschaftliche Erforschung des Landes Salzburg, Stand 1963. E.P.Tratz-Festschrift zum 75. Geburtstag der naturwissenschaftlichen Arbeitsgemeinschaften am Haus der Natur, Imst.
Swan M.J.S. \& Oldham R.S. 1994. - Amphibians and landscape composition. Pages 176-183 in Fragmentationin agricultural landscapes. Dover J.E. (ed.). Proc. 3rd annual Internat. Assoc. Landscape Ecol., Preston.

Sztatecsny M., Jehle R., Schmidt B.R. \& Arntzen J.W. 2004. - The abundance of premetamorphic newts (Triturus cristatus, T. marmoratus) as a function of habitat determinants: an a priori model selection approach. Herpetol.l Journal, 14, 89-97.

Thiesmeier B. \& Kupfer A. 2000. - Der Kammmolch: Ein Wasserdrache in Gefahr. Laurenti, Bochum, 158 p.

Van Buskirk J. 2005 - Local and landscape influence on amphibian occurrence and abundance. Ecology, 86, 1936-1947.

Wake D.B. 1991. - Declining amphibian populations. Science, 253, 860.

Williams P., Biggs J., Whitfield M., Thorne A., Bryant S., Fox G. \& Nicolet P. 1999. - The pond book: A guide to the management and creation of ponds. Ponds conservation trust, Oxford, $105 \mathrm{p}$.

Wolterstorff W. 1925. - Katalog der Amphibien-Sammlung im Museum für Natur- und Heimatkunde zu Magdeburg. Abhandlungen und Berichte für Naturkunde, Museum Magdeburg, 4, 155-310.

Wood P.J., Greenwood M.T. \& Agnew M.D. 2003. - Pond biodiversity and habitat loss in the UK. Area, 35, 206-216. 